\title{
Production of cuttings and nutrient export by Coffea canephora in different periods in the Southwestern Amazon
}

\author{
Patrícia A. Bazoni ${ }^{1}$, Marcelo C. Espindula ${ }^{2}$, Larissa F. B. de Araújo ${ }^{1}$, Jaqueline M. Vasconcelos ${ }^{3}$ \& \\ Marcela Campanharo ${ }^{3}$
} ${ }^{1}$ Fundação Universidade Federal de Rondônia/Programa de Pós-graduação em Ciências Ambientais, Rolim de Moura, RO, Brasil. E-mail:
patriciabazoni.agro@gmail.com - ORCID: 0000-0003-0922-9947; larissafarelli@gmail.com - ORCID: 0000-0003-4249-024X
${ }^{2}$ Empresa Brasileira de Pesquisa Agropecuária, Porto Velho, RO, Brasil. E-mail: marcelo.espindula@embrapa.br (Corresponding author) ORCID:
0000-0001-7481-9746
${ }^{3}$ Fundação Universidade Federal de Rondônia/Departamento de Biologia, Porto Velho, RO, Brasil. E-mail: jaqueline.vasconcelos@unir.br - ORCID:
0000-0002-6404-2168; marcela.campanharo@unir.br - ORCID: 0000-0003-3037-1411

\begin{abstract}
Cutting is the main vegetative propagation method used for the production of Coffea canephora plantlets. In this method, parent plants are conducted in a specific field, called clonal garden, which must be managed to produce clonal cuttings. The objective of this study was to evaluate the production of cuttings and the export of nutrients by Coffea canephora in different periods in the Southwestern Amazon. The experiment was carried out in a $6 \times 3$ split-plot scheme (repeated measures in time), consisting of the combination of six clonal Coffea canephora genotypes (plot) and three cutting collection periods (subplots). The genotypes were: C-057, C-088, C-089, C-125, C-130 and C-160; and the evaluation sampling times were January/2017, May/2017 and September/2017. The applied design was a completely randomized design with four repetitions. The dry season, from May to September, promotes lower orthotropic stem dry mass accumulation by Coffea canephora, but allows obtaining a larger number of viable cuttings for the production of clonal plantlets. Nutrient accumulation by orthotropic stems for cutting production follows the following order: $\mathrm{N}>\mathrm{K}>\mathrm{Ca}$ $>\mathrm{Mg}>\mathrm{S}>\mathrm{P}>\mathrm{Mn}>\mathrm{Fe}>\mathrm{Zn}>\mathrm{Cu}$. Nutrient export by the cuttings follows a descending order: $\mathrm{K}>\mathrm{N}>\mathrm{Ca}$ $>\mathrm{Mg}>\mathrm{P}>\mathrm{S}>\mathrm{Mn}>\mathrm{Fe}>\mathrm{Zn}>\mathrm{Cu}$.
\end{abstract}

Key words: conilon coffee, clonal genotypes, vegetative propagules

\section{Produção de estacas e exportação de nutrientes por Coffea canephora em diferentes épocas na Amazônia Sul Ocidental}

RESUMO: A estaquia é o principal método de propagação vegetativa utilizado na produção de mudas de Coffea canephora. Neste método, são utilizadas matrizes conduzidas em um campo específico, denominado de jardim clonal, que deve ser manejado para produção de estacas clonais. Assim, objetivou-se avaliar a produção de estacas e a exportação de nutrientes por cafeeiros Coffea canephora em diferentes épocas na Amazônia Sul Ocidental. O experimento foi conduzido em esquema de parcelas subdivididas no tempo, $6 \times$ 3 , formado pela combinação de seis genótipos clonais de Coffea canephora (parcela) e três épocas de coleta de estacas (sub parcelas). Os genótipos foram: C-057, C-088, C-089, C-125, C-130 e C-160; e as épocas de coleta de avaliação foram: janeiro/2017, maio/2017 e setembro/2017. O delineamento foi o inteiramente casualizado com quatro repetições. O período de estiagem, que foi de maio a setembro, proporciona menor acúmulo de massa seca de hastes ortotrópicas por plantas matrizes de Coffea canephora, porém, possibilita a obtenção de maior número de estacas viáveis para produção de mudas clonais. $\mathrm{O}$ acúmulo de nutrientes pelas hastes ortotrópicas destinadas a produção de estacas segue a seguinte ordem: $\mathrm{N}>\mathrm{K}>\mathrm{Ca}>\mathrm{Mg}>\mathrm{S}>\mathrm{P}$ $>\mathrm{Mn}>\mathrm{Fe}>\mathrm{Zn}>\mathrm{Cu}$. A exportação de nutrientes pelas estacas segue ordem decrescente: $\mathrm{K}>\mathrm{N}>\mathrm{Ca}>\mathrm{Mg}$ $>\mathrm{P}>\mathrm{S}>\mathrm{Mn}>\mathrm{Fe}>\mathrm{Zn}>\mathrm{Cu}$.

Palavras-chave: café conilon, genótipos clonais, propágulos vegetativos 


\section{INTRODUCTION}

The formation of high-yielding commercial orchards of Coffea canephora is directly linked to the use of good-quality plantlets (Ferrão et al., 2017). Cutting stands out as a method of vegetative propagation which ensures the maintenance of the genetic characteristics of the parent plant (Souza et al., 2015). In addition to genetic quality, plantlets must show sanitary and physiological quality.

The main factor that will determine the sanitary and physiological quality of the plantlets is the health of the parent plant. Although the technical recommendations indicate the exclusive use of parent plants for the production of cuttings, in the Amazon, cuttings have been collected in commercial orchards. As a consequence, the beginning of plantlet production is restricted to the months from July to September, corresponding to three, four or five months after the harvest and preparation of the parent plants. Thus, the period of planting the plantlets in the field is restricted to the months from October to December (Espindula et al., 2015) and from January to February.

Although the months from October to February are considered favorable for planting because they have high levels of precipitation, planting in this period results in a poor harvest in the first year after planting (Partelli et al., 2006), being economically unfeasible. As a way to solve this problem, the use of technologies such as irrigation has allowed the planting period to be altered and coffee orchards to be planted throughout the year.

However, C. canephora has seasonal variations in its growth along the year, a fact mainly influenced by the climatic conditions (Dubberstein et al., 2017), which may result in different nutritional composition of the vegetative aerial parts and, consequently, of the cuttings that will originate the plantlets. Thus, the objective of this study was to evaluate the productive capacity and nutritional composition of orthotropic stems of $C$. canephora coffee plants intended for the production of cuttings in different periods of the year in Southwestern Amazon.

\section{Material ANd Methods}

The experiment was conducted in the Experimental Area of EMBRAPA ( $10^{\circ} 43^{\prime} 55^{\prime \prime} \mathrm{S}$; $62^{\circ} 15^{\prime} 19^{\prime \prime} \mathrm{W}$, at an altitude of $300 \mathrm{~m}$ ), in the municipality of Ouro Preto do Oeste, Rondônia, Brazil, from September 2016 to September 2017. The predominant climate in the region is rainy tropical - Aw (Alvares et al., 2013), with an average annual temperature of $25^{\circ} \mathrm{C}$ and average precipitation of $2,000 \mathrm{~mm}$ year ${ }^{-1}$. The rainy season occurs from October-November until April-May.

The experimental area consisted of an orchard of $C$. canephora, 'Conilon - BRS Ouro Preto' variety, planted for the exclusive purpose of producing cuttings in a soil classified as Ultisol. The orchard was planted in 2012, with spacing of 2.5 $\mathrm{m}$ between rows and $1.5 \mathrm{~m}$ between plants. Fertilization was performed following technical recommendations for the crop, intended for fruit production (Marcolan et al., 2015).
The experiment was conducted in a $6 \times 3$ split-plot scheme (repeated measures in time), consisting of six genotypes and three periods of cutting harvesting (January/2017, May/2017 and September/2017). The genotypes C-057, C-088, C-089, C-125, C-130 and C-160 of the variety Conilon - BRS Ouro Preto were used because they have similar phenotypic characteristics and because they represent the average behavior of this variety, which is composed of 15 genotypes (Ramalho et al., 2014). The experimental design was completely randomized with four repetitions.

The average values of minimum, mean and maximum temperature and air relative humidity and the precipitation along the experimental period were obtained by an automatic weather station installed in the above-mentioned experimental area (Figures 1A, B and C). To replace the evapotranspired

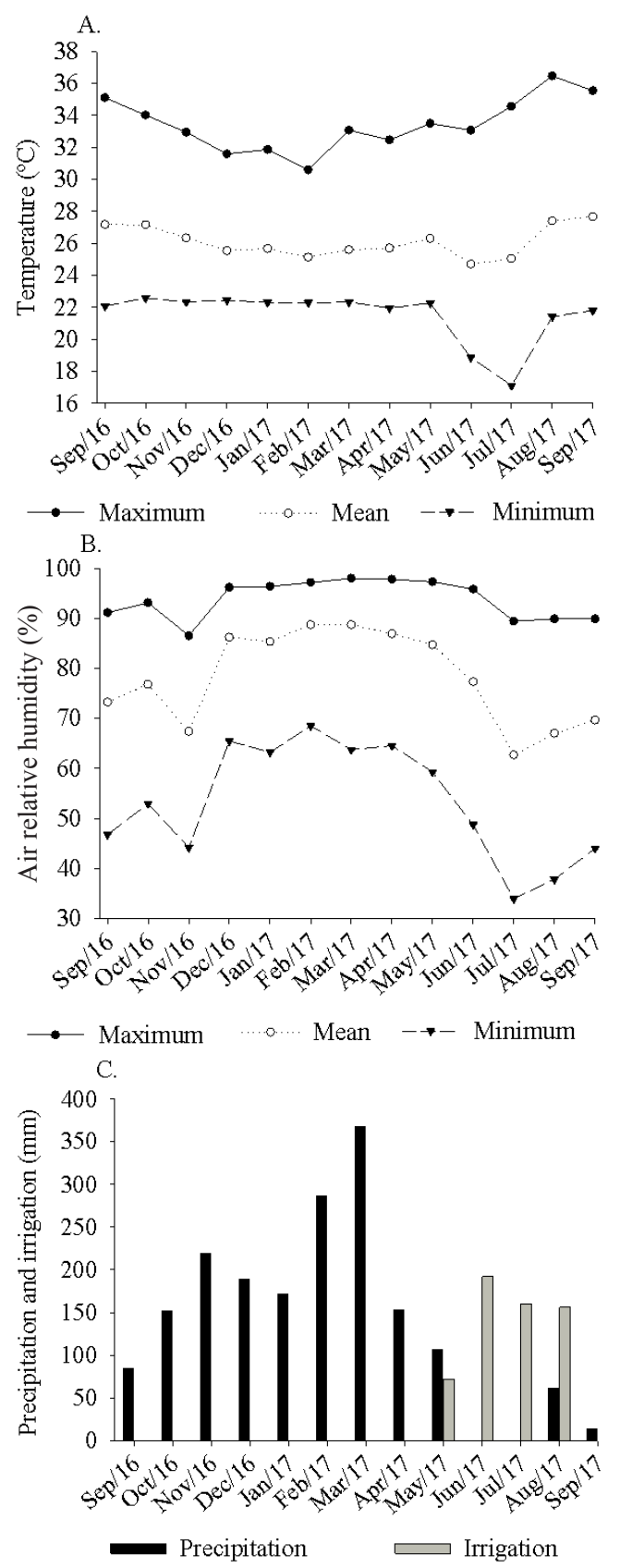

Figure 1. Minimum, mean and maximum air temperature (A); minimum, mean and maximum air relative humidity $(\mathrm{B})$; and accumulated precipitation and complementary irrigation (C) along the experimental period 
water, complementary irrigation was performed using a conventional sprinkler system along the months of drought (Figure 1C).

The last fertilization of the parent plants, prior to experiment installation, was carried out in August 2016 (45 days before the experiment). This fertilization consisted of $150 \mathrm{~g}$ of 20-05-20, $50 \mathrm{~g}$ of $\mathrm{MIB}(\mathrm{B}=1.8 \% ; \mathrm{Cu}=0.8 \% ; \mathrm{Fe}=3.0 \% ; \mathrm{Mn}=2.0 \% ; \mathrm{Mo}$ $=0.1 \%), 20 \mathrm{~g}$ of boric acid and $20 \mathrm{~g}$ of magnesium sulfate. In order to neutralize exchangeable aluminum and increase $\mathrm{Ca}$ and $\mathrm{Mg}$ contents, $200 \mathrm{~g}$ plant $^{-1}$ of dolomitic limestone (RNV $100 \%$ ) was applied broadcast, $100 \mathrm{~g}$ on each side of the plant, covering approximately $1 \mathrm{~m}^{2}$ of the soil.

Prior to installation of experiment (September/2016), the area was characterized by soil analysis in the 0-20 and 20-40 $\mathrm{cm}$ layers. In the first layer, the results were: $\mathrm{pH}=5.6$ in water; $\mathrm{P}=46.5 \mathrm{mg} \mathrm{dm}^{-3} ; \mathrm{K}, \mathrm{Ca}, \mathrm{Mg}, \mathrm{H}+\mathrm{Al}, \mathrm{Al}$ and $\mathrm{CEC}=0.57,2.13$, $0.59,4.8,0.22$ and $8.18 \mathrm{cmol}_{\mathrm{c}} \mathrm{dm}^{-3}$, respectively, $\mathrm{OM}=15.3 \mathrm{~g}$ $\mathrm{kg}^{-1}$; Cu, Fe, $\mathrm{Mn}$ and $\mathrm{Zn}=11,95.19,196.49$ and27.6 $\mathrm{mg} \mathrm{dm}^{-3}$, respectively. In the $20-40 \mathrm{~cm}$ layer, the results were: $\mathrm{pH}=6.3$ in water; $\mathrm{P}=34 \mathrm{mg} \mathrm{dm}^{-3} ; \mathrm{K}, \mathrm{Ca}, \mathrm{Mg}, \mathrm{H}+\mathrm{Al}, \mathrm{Al}$ and $\mathrm{CEC}=$ $0.46,3.68,0.94,1.7,0$ and $6.73 \mathrm{cmol}_{\mathrm{c}} \mathrm{dm}^{-3}$, respectively; $\mathrm{OM}$ $=5.8 \mathrm{~g} \mathrm{~kg}^{-1} ; \mathrm{Cu}, \mathrm{Fe}, \mathrm{Mn}$ and $\mathrm{Zn}=7.16,79.2,158.03$ and 14.76 $\mathrm{mg} \mathrm{dm}{ }^{-3}$, respectively.

The parent plants intended for the production of cuttings were all standardized at the time of experiment installation (September/2016) with four orthotropic stems and induced to produce secondary shoots. To induce the shoots, two opposing stems received apical pruning, remaining with 1.70 $\mathrm{m}$ height from the soil level. All productive branches that were more than $30 \mathrm{~cm}$ long were removed. Foliar evaluation of the plants at the time of experiment installation indicated the following contents: $\mathrm{N}, \mathrm{P}, \mathrm{K}, \mathrm{Ca}, \mathrm{Mg}$ and $\mathrm{S}=35,1.09,26.9$, $41.4,3.31$ and $2.29 \mathrm{~g} \mathrm{~kg}^{-1}$, respectively, and $\mathrm{Cu}, \mathrm{Fe}, \mathrm{Mn}$ and $\mathrm{Zn}$ $=37.31,310.5,769.9$ and $54.5 \mathrm{mg} \mathrm{kg}^{-1}$ dry mass, respectively. During each growth cycle of the stems, $150 \mathrm{~g}$ of the 20-05-20 formulation were applied, split into two applications at 20 and 45 days after pruning.

The cuttings were produced from orthotropic stems collected in each one of the months indicated in the treatments. The apical and basal portions of the stems were eliminated using pruning shears. After that, all plagiotropic branches and $2 / 3$ of the blade of each leaf were removed. Finally, the cuttings were individualized with two straight cuts: one immediately above the insertion point of the plagiotropic branches and the other at $5 \mathrm{~cm}$ below the insertion point of the pair of leaves (Aquino et al., 2017).

In each evaluation period, the following variables were measured: number of viable cuttings per parent plant, dry mass of viable cuttings, total dry mass of orthotropic stems, nutrient accumulation in orthotropic stems and the export of nutrients by the cuttings: nitrogen $(\mathrm{N})$, phosphorus $(\mathrm{P})$, potassium $(\mathrm{K})$, calcium $(\mathrm{Ca})$, magnesium $(\mathrm{Mg})$, sulfur $(\mathrm{S})$, copper $(\mathrm{Cu})$, zinc $(\mathrm{Zn})$, iron (Fe) and manganese (Mn).

To determine the nutrient accumulation in orthotropic stems, the vegetative material was collected in each evaluation period. After collection, the plant materials were placed in paper bags and taken to the oven, being exposed to a temperature of $65^{\circ} \mathrm{C}$ until reaching constant mass. Subsequently, the samples were ground and subjected to the analysis of the nutrient contents. Nitric-perchloric chemical digestion was used for the nutrients $\mathrm{P}, \mathrm{K}, \mathrm{Ca}, \mathrm{Mg}, \mathrm{Mn}, \mathrm{Fe}, \mathrm{Zn}$ and $\mathrm{Cu}$, followed by analytical determination by plasma spectrometry for $\mathrm{Ca}$, $\mathrm{Mg}, \mathrm{Mn}, \mathrm{Fe}, \mathrm{Zn}$ and $\mathrm{Cu}$. $\mathrm{P}$ was determined by molecular spectrophotometry and $\mathrm{K}$ by flame photometry. $\mathrm{N}$ was obtained by sulfuric acid digestion and determined after distillation by the semi-micro Kjeldahl method (Carmo et al., 2000).

The accumulation of nutrients in the orthotropic stems of the coffee plant was calculated by multiplying the nutrient contents by the respective values of dry mass of the orthotropic stems $(\mathrm{Acc}=\mathrm{DMOS} \times \mathrm{C})$, in which Acc - nutrient accumulation, DMOS - dry mass of orthotropic stems, and $\mathrm{C}$ - nutrient content.

Nutrient export by the cuttings was determined by multiplying the nutrient concentration found in viable cuttings by the respective dry mass values of the cuttings ( $\mathrm{E}=\mathrm{DMVC}$ $\times \mathrm{C}$ ), in which E - nutrient export, DMVC - dry mass of viable cuttings, and $\mathrm{C}$ - nutrient content. The results were expressed in gram or milligram per plant.

The data were subjected to the Lilliefors' test for normality assessment. The variables number of cuttings, dry mass of cuttings and orthotropic stems, $\mathrm{K}$ accumulation and $\mathrm{S}$ accumulation followed normal distribution. The other data were transformed to $V_{\mathrm{x}}$ or $\log \mathrm{x}$, in order to obtain normal distribution. After transformation, analysis of variance and $\mathrm{F}$ test were carried out at $\mathrm{p} \leq 0.05$. The means were compared by Tukey and Scott-Knott tests $(\mathrm{p} \leq 0.05)$, using the statistical program GENES。

\section{Results And Discussion}

There was interaction between the factors dry mass of the orthotropic stems and the accumulation of $\mathrm{N}, \mathrm{P}, \mathrm{K}, \mathrm{Ca}, \mathrm{Mg}$, $\mathrm{Cu}$ and $\mathrm{Mn}$ in the orthotropic stems. For the cuttings, there was only interaction for the export of $\mathrm{Zn}$ and $\mathrm{Cu}$.

The highest number and dry mass of cuttings were obtained in September, compared to the periods of January and May (Table 1). This suggests that parent plants of C. canephora that originated these cuttings invested more photoassimilates in the formation of nodes than in internode elongation, that is, they produced shorter internodes.

Such reduction in the elongation of the orthotropic stem may be associated with the increase of temperatures and reduction in the air relative humidity observed during the growth period of the stems (Figure 1), since recent studies carried out with this species have shown that exposure to supraoptimal temperatures alone does not have any negative effect on photosynthesis and, consequently, on growth (Martins et al., 2016; Rodrigues et al., 2016). However, high temperatures associated with reduction in the air relative humidity lead to increased vapor pressure deficit. Such increment reduces plant growth due to stomatal limitations which interfere with the production of carbohydrates through photosynthesis (Thioune et al., 2017; Rodrigues et al., 2018).

In addition, the lowest dry mass accumulation in the orthotropic stems (Table 1) observed in September may be associated with the lower $\mathrm{Zn}$ accumulation found in the stems in this period. $\mathrm{Zn}$ participates in the synthesis of the amino 
Table 1. Number of cuttings, dry mass of cuttings and dry mass of orthotropic stems of 'Conilon' Coffea canephora genotypes evaluated in different periods of the year

\begin{tabular}{|c|c|c|c|c|c|c|c|c|}
\hline \multirow{3}{*}{ Genolype } & Jan & May & Sep & Mean & Jan & May & Sep & Mean \\
\hline & \multicolumn{4}{|c|}{ Number of cuttings } & \multicolumn{4}{|c|}{ Dry mass of cuttings } \\
\hline & \multicolumn{4}{|c|}{ (cuttings plant $^{-1}$ ) } & \multicolumn{4}{|c|}{$\left(g\right.$ plant $\left.^{-1}\right)$} \\
\hline C-057 & 128 & 146 & 222 & $165 \mathrm{a}$ & 135 & 189.6 & 270.4 & $198.3 \mathrm{a}$ \\
\hline C-088 & 149 & 157 & 194 & $166 \mathrm{a}$ & 163.2 & 214.7 & 232.5 & $203.5 \mathrm{a}$ \\
\hline C-089 & 110 & 124 & 174 & $136 \mathrm{a}$ & 120.6 & 130.1 & 168.1 & $139.6 \mathrm{a}$ \\
\hline C-125 & 120 & 124 & 175 & $139 \mathrm{a}$ & 156.6 & 178.9 & 228.6 & $188 \mathrm{a}$ \\
\hline C-130 & 116 & 130 & 174 & $140 \mathrm{a}$ & 140.9 & 175.4 & 197.9 & $171.4 \mathrm{a}$ \\
\hline C-160 & 117 & 119 & 187 & $141 \mathrm{a}$ & 145.3 & 136.1 & 210.1 & $163.8 \mathrm{a}$ \\
\hline Mean & $123 \mathrm{~B}$ & $133 \mathrm{~B}$ & $187 \mathrm{~A}$ & 148 & $143.6 \mathrm{~B}$ & $170.8 \mathrm{AB}$ & $217.9 \mathrm{~A}$ & 175.5 \\
\hline CV $(\%)^{1}$ & \multicolumn{4}{|c|}{31.29} & \multicolumn{4}{|c|}{33.32} \\
\hline \multirow[t]{4}{*}{ CV $(\%)^{2}$} & \multicolumn{4}{|c|}{15.68} & \multicolumn{4}{|c|}{22.11} \\
\hline & \multicolumn{2}{|c|}{ January } & \multicolumn{2}{|c|}{ May } & \multicolumn{2}{|c|}{ September } & \multicolumn{2}{|c|}{ Mean } \\
\hline & \multicolumn{8}{|c|}{ Dry mass of orthotropic stems } \\
\hline & \multicolumn{8}{|c|}{$\left(\right.$ (g plant $\left.{ }^{-1}\right)$} \\
\hline C-S057 & \multicolumn{2}{|c|}{$1,754 \mathrm{ABb}$} & \multicolumn{2}{|c|}{$\begin{array}{l}2,128 \mathrm{Aa} \\
1971 \mathrm{Aa}\end{array}$} & \multicolumn{2}{|c|}{ 1,357 Ba } & \multicolumn{2}{|c|}{$1,746 a$} \\
\hline C-S088 & \multicolumn{2}{|c|}{$2,118 \mathrm{Aa}$} & \multirow{2}{*}{\multicolumn{2}{|c|}{$\begin{array}{c}1,971 \mathrm{Aa} \\
1,320 \mathrm{Abc}\end{array}$}} & \multicolumn{2}{|c|}{$1,135 \mathrm{Ba}$} & \multicolumn{2}{|c|}{$1,741 \mathrm{a}$} \\
\hline C-S089 & \multicolumn{2}{|c|}{$1,387 \mathrm{Ac}$} & & & \multicolumn{2}{|c|}{$830 \mathrm{Bb}$} & \multicolumn{2}{|c|}{$1,179 a$} \\
\hline C-125 & \multicolumn{2}{|c|}{$1,946 \mathrm{Aa}$} & & \multicolumn{2}{|c|}{ 1,163 Ba } & \multicolumn{2}{|c|}{$1,605 \mathrm{a}$} \\
\hline C-130 & \multicolumn{2}{|c|}{$1,456 \mathrm{ABc}$} & \multicolumn{2}{|c|}{$1,925 \mathrm{Aa}$} & & & & \\
\hline C-160 & & & & & & & & \\
\hline Mean & & & & & & & & \\
\hline CV $(\%)^{1}$ & & & & & 30.13 & & & \\
\hline $\mathrm{CV}(\%)^{2}$ & & & & & 11.91 & & & \\
\hline
\end{tabular}

Means followed by the same letters, uppercase in the row and lowercase in the column, do not differ by Tukey and Scott-Knott tests, respectively, both at $\mathrm{p} \leq 0.05 ;{ }^{1}$ Coefficient of variation of the subplot (period); ${ }^{2}$ Coefficient of variation of the plot (genotype)

acid tryptophan and is a precursor of indole acetic acid (AIA), a phytohormone related to cell growth and elongation and protein synthesis (Sadeghzadeh, 2013), whose lower availability in the plant is characterized by a reduction in the growth of internodes (Taiz et al., 2017). Thus, the lower internode elongation may have allowed an increase of nodes in the orthotropic stems, with consequent increase in the production of viable cuttings.

On the other hand, there was a lower production of viable cuttings and lower mass of cuttings, although there was higher production of dry mass of orthotropic stems in the periods of January and May (Table 1). This suggests that the stems showed elongation, which resulted in the growth of the internodes, to the detriment of the formation of nodes. This behavior may be associated with lower exposure of parent plants to solar radiation during the stem formation period (INPE, 2018), a condition that is determinant for promoting changes in growth pattern (Partelli et al., 2014), leading to etiolation of the branches.

Regarding macronutrient accumulation, in general, the orthotropic stems collected in September showed lower accumulation of nutrients, except sulfur, for which there was no difference in the accumulation between the production periods (Table 2). This lower nutrient accumulation observed in the orthotropic stems is possibly related to the flowering of the coffee plant, which occurred between August and September, because, during the reproductive stage, the flowers function as a strong sink of nutrients, especially $\mathrm{N}$ and $\mathrm{K}$, absorbing 20 to $25 \%$ of the nutrients accumulated in the leaves (Laviola et al., 2006).

In addition, in the case of $S$, this is an element considered of low mobility in the phloem (Taiz et al., 2017). In the plant, sulfate is the main form of $S$ reserve, and it is not easily remobilized to young leaves (Lavres Junior et al., 2009), which justifies the similar S accumulation in all periods of production of orthotropic stems, as they constituted the main sink.

Regarding the effect of the genotypes, there was no uniformity of behavior for the accumulation of nutrients in the different periods evaluated, i.e., no genotype stood out positively or negatively, in general, from the others. There were only specific results that do not allow the genotypes to differentiated in relation to their behavior in terms of nutrient accumulation in the vegetative aerial part (Tables 2 and 3 ).

The difference in the accumulation of macro- and micronutrients found in the orthotropic stems collected in different periods and for the various genotypes of $C$. canephora (Tables 2 and 3) suggest that there is discrimination in terms of nutrient use efficiency among the genotypes (Amaral et al., 2011). However, considering that, regardless of the genotypes, September was the month which led to the lowest accumulation for most nutrients, except for $\mathrm{Cu}$ and $\mathrm{Fe}$. These results suggest that the environmental conditions to which the parent plants were exposed during the growth of the stems influenced more the accumulation of nutrients than the individual capacity of each genotype to absorb and translocate nutrients.

Indeed, nutrient accumulation by plants depends on several factors, such as genotype (Amaral et al., 2011), age, plant organs and tissues, availability of light (Araújo et al., 2015) and environmental conditions (Prezotti \& Bragança et al., 2013). In the case of the effect of genotypes, the impossibility of identifying dissimilar genotypes, in general, is due to the fact that the genotypes of the variety Conilon - BRS Ouro Preto have been selected and grouped according to their phenotypic characteristics (Ramalho et al., 2014).

In relation to the export of macronutrients, the cuttings from orthotropic stems produced in September had higher values, regardless of the genotype, except for phosphorus, whose export did not differ between the months of May and 
Table 2. Macronutrients accumulated in the vegetative dry mass (orthotropic stems) of 'Conilon' Coffea canephora genotypes in different periods of the year

\begin{tabular}{|c|c|c|c|c|c|c|c|c|}
\hline \multirow{3}{*}{ Genotype } & Jan & May & Sep & Mean & Jan & May & Sep & Mean \\
\hline & \multicolumn{4}{|c|}{$\mathrm{N}$ accumulation in stems } & \multicolumn{4}{|c|}{$P$ accumulation in stems } \\
\hline & \multicolumn{8}{|c|}{$\left(\right.$ g plant $\left.t^{-1}\right)$} \\
\hline C-057 & $55 \mathrm{ABa}$ & $61.2 \mathrm{Aa}$ & $38.8 \mathrm{Ba}$ & $51.6 \mathrm{a}$ & $2.41 \mathrm{Ba}$ & $3.74 \mathrm{Aa}$ & $1.96 \mathrm{Ba}$ & $2.7 \mathrm{a}$ \\
\hline C-088 & $66.5 \mathrm{Aa}$ & $62.7 \mathrm{Aa}$ & $34.1 \mathrm{Ba}$ & $54.4 \mathrm{a}$ & $2.79 \mathrm{Aa}$ & $3.48 \mathrm{Aa}$ & $1.72 \mathrm{Ba}$ & $2.66 \mathrm{a}$ \\
\hline C-089 & $42.8 \mathrm{Ab}$ & $39.1 \mathrm{ABC}$ & $26 \mathrm{Bb}$ & $35.9 \mathrm{a}$ & $1.97 \mathrm{Ab}$ & $2.13 \mathrm{Ab}$ & 1.12 Ba & $1.74 \mathrm{a}$ \\
\hline C-125 & $61.3 \mathrm{Aa}$ & $56.8 \mathrm{Aa}$ & $33.9 \mathrm{Ba}$ & $50.6 \mathrm{a}$ & $2.74 \mathrm{Aa}$ & $2.73 \mathrm{Ab}$ & $1.51 \mathrm{Ba}$ & $2.32 \mathrm{a}$ \\
\hline C-130 & $48.2 \mathrm{Ab}$ & $51.4 \mathrm{Ab}$ & $27.8 \mathrm{Bb}$ & $42.4 \mathrm{a}$ & $1.85 \mathrm{Bb}$ & $2.35 \mathrm{Ab}$ & $1.28 \mathrm{Bb}$ & $1.82 \mathrm{a}$ \\
\hline C-160 & $65.8 \mathrm{Aa}$ & $44.7 \mathrm{ABC}$ & $31.6 \mathrm{Bb}$ & $47.3 \mathrm{a}$ & $2.7 \mathrm{Aa}$ & $2.4 \mathrm{ABb}$ & $1.6 \mathrm{Ba}$ & $2.23 a$ \\
\hline Mean & $56.6 \mathrm{~A}$ & $52.6 \mathrm{~A}$ & $32 \mathrm{~B}$ & 47.1 & $2.41 \mathrm{~A}$ & $2.8 \mathrm{~A}$ & $1.53 \mathrm{~B}$ & 2.24 \\
\hline CV $(\%)^{1}$ & \multicolumn{4}{|c|}{17.86} & \multicolumn{4}{|c|}{17.85} \\
\hline \multirow[t]{3}{*}{$\mathrm{CV}(\%)^{2}$} & \multicolumn{4}{|c|}{6.37} & \multicolumn{4}{|c|}{7.22} \\
\hline & \multicolumn{4}{|c|}{$\mathrm{K}$ accumulation in stems } & \multicolumn{4}{|c|}{ Ca accumulation in stems } \\
\hline & \multicolumn{8}{|c|}{ (g plant $^{-1}$ ) } \\
\hline C-057 & $45.3 \mathrm{ABC}$ & $54.4 \mathrm{Aa}$ & $35.3 \mathrm{Ba}$ & $45 \mathrm{a}$ & $24.7 \mathrm{Ab}$ & $26.7 \mathrm{Aa}$ & $15.9 \mathrm{Ba}$ & $22.4 \mathrm{a}$ \\
\hline C-088 & $55.2 \mathrm{Ab}$ & $58.2 \mathrm{Aa}$ & $34.5 \mathrm{Ba}$ & $49.3 \mathrm{a}$ & $30.8 \mathrm{Aa}$ & $23.8 \mathrm{Aa}$ & $13.9 \mathrm{Ba}$ & $22.8 \mathrm{a}$ \\
\hline C-089 & $36.9 \mathrm{Ac}$ & $35.7 \mathrm{Ab}$ & $23.7 \mathrm{Ab}$ & $32.1 \mathrm{a}$ & $13.1 \mathrm{AC}$ & $12 \mathrm{Ac}$ & $9.9 \mathrm{Ab}$ & $11.7 \mathrm{a}$ \\
\hline C-125 & $64.3 \mathrm{Aa}$ & $54.6 \mathrm{Aa}$ & $32.8 \mathrm{Ba}$ & $50.6 \mathrm{a}$ & $15.9 \mathrm{Ac}$ & $12.9 \mathrm{Ac}$ & $11.4 \mathrm{Ab}$ & $13.4 \mathrm{a}$ \\
\hline C-130 & $40.4 \mathrm{Ac}$ & $44.4 \mathrm{Ab}$ & $23.1 \mathrm{Bb}$ & $36 \mathrm{a}$ & $14.6 \mathrm{Ac}$ & $16.8 \mathrm{Ab}$ & $8.6 \mathrm{Bb}$ & $13.3 \mathrm{a}$ \\
\hline C-160 & $54.9 \mathrm{Ab}$ & $40.6 \mathrm{ABb}$ & $32.9 \mathrm{Ba}$ & $42.8 \mathrm{a}$ & $24.9 \mathrm{Ab}$ & $17.1 \mathrm{ABb}$ & $12.7 \mathrm{Bb}$ & $18.2 \mathrm{a}$ \\
\hline Mean & $49.5 \mathrm{~A}$ & $48 \mathrm{~A}$ & $30.4 \mathrm{~B}$ & 42.6 & $20.7 \mathrm{~A}$ & $18.2 \mathrm{~A}$ & $12.1 \mathrm{~B}$ & 17 \\
\hline CV $(\%)^{1}$ & \multicolumn{4}{|c|}{30.45} & \multicolumn{4}{|c|}{14.25} \\
\hline \multirow[t]{3}{*}{ CV $(\%)^{2}$} & \multicolumn{4}{|c|}{14.59} & \multicolumn{4}{|c|}{6.40} \\
\hline & \multicolumn{4}{|c|}{$\mathrm{Mg}$ accumulation in stems } & \multicolumn{4}{|c|}{$S$ accumulation in stems } \\
\hline & \multicolumn{8}{|c|}{ (g plant $\left.^{-1}\right)$} \\
\hline C-057 & $4 \mathrm{ABb}$ & $4.7 \mathrm{Aa}$ & $2.8 \mathrm{Ba}$ & $3.8 \mathrm{a}$ & 2.96 & 3.3 & 2.39 & $2.88 \mathrm{a}$ \\
\hline C-088 & $5.8 \mathrm{Aa}$ & $5.7 \mathrm{Aa}$ & $3 \mathrm{Ba}$ & $4.8 \mathrm{a}$ & 3.27 & 2.99 & 2.4 & $2.89 \mathrm{a}$ \\
\hline C-089 & $3.2 \mathrm{Ac}$ & $3 \mathrm{Ac}$ & $2.1 \mathrm{Ab}$ & $2.7 \mathrm{a}$ & 1.72 & 1.85 & 1.57 & $1.71 \mathrm{a}$ \\
\hline C-125 & $5.1 \mathrm{Aa}$ & $5.2 \mathrm{Aa}$ & $3.3 \mathrm{Ba}$ & $4.5 \mathrm{a}$ & 2.71 & 1.96 & 2.14 & $2.27 \mathrm{a}$ \\
\hline C-130 & $3 \mathrm{ABC}$ & $3.6 \mathrm{Ab}$ & $2.2 \mathrm{Bb}$ & $2.9 \mathrm{a}$ & 2.56 & 2.4 & 1.83 & $2.27 \mathrm{a}$ \\
\hline C-160 & $5.3 \mathrm{Aa}$ & $4.1 \mathrm{ABb}$ & $3.1 \mathrm{Ba}$ & $4.1 \mathrm{a}$ & 2.45 & 2.05 & 1.54 & $2.01 \mathrm{a}$ \\
\hline Mean & $4.4 \mathrm{~A}$ & $4.3 \mathrm{~A}$ & $2.7 \mathrm{~B}$ & 3.8 & $2.61 \mathrm{~A}$ & $2.42 \mathrm{~A}$ & $1.98 \mathrm{~A}$ & 2.34 \\
\hline CV $(\%)^{1}$ & \multicolumn{4}{|c|}{17.06} & \multicolumn{4}{|c|}{40.65} \\
\hline CV $(\%)^{2}$ & \multicolumn{4}{|c|}{6.66} & \multicolumn{4}{|c|}{21.46} \\
\hline
\end{tabular}

Means followed by the same letters, uppercase in the row and lowercase in the column, do not differ by Tukey and Scott-Knott tests, respectively, both at $\mathrm{p} \leq 0.05$ level; $\mathrm{N}$ - Nitrogen P - Phosphorus; K - Potassium; Ca - Calcium; Mg - Magnesium; S - Sulfur; ${ }^{1}$ Coefficient of variation of the subplot (period); ${ }^{2}$ Coefficient of variation of the plot (genotype)

Table 3. Micronutrients accumulated in the vegetative dry mass (orthotropic stems) of 'Conilon' Coffea canephora genotypes in different periods of the year

\begin{tabular}{|c|c|c|c|c|c|c|c|c|}
\hline \multirow{3}{*}{ Genotype } & Jan & May & Sep & Mean & Jan & May & Sep & Mean \\
\hline & \multicolumn{4}{|c|}{ Cu accumulation in stems } & \multicolumn{4}{|c|}{ Fe accumulation in stems } \\
\hline & \multicolumn{8}{|c|}{$\left(\right.$ (mg plant $\left.^{-1}\right)$} \\
\hline C-057 & $47 \mathrm{Aa}$ & $49.9 \mathrm{Aa}$ & $58.2 \mathrm{Aa}$ & $47 a$ & 84 & 392 & 447 & $308 a$ \\
\hline C-088 & $62.1 \mathrm{Aa}$ & $46.2 \mathrm{ABa}$ & $38.5 \mathrm{Bb}$ & $62.1 \mathrm{a}$ & 126 & 335 & 516 & $326 a$ \\
\hline C-089 & $44.3 \mathrm{Aa}$ & $38.5 \mathrm{Aa}$ & $31.4 \mathrm{Ab}$ & $44.3 \mathrm{a}$ & 77 & 295 & 378 & $250 \mathrm{a}$ \\
\hline C-125 & $47.4 \mathrm{Aa}$ & $47.3 \mathrm{Aa}$ & $49 \mathrm{Aa}$ & $47.4 \mathrm{a}$ & 185 & 397 & 533 & $372 \mathrm{a}$ \\
\hline C-130 & $29.1 \mathrm{Bb}$ & $58.6 \mathrm{Aa}$ & $39 \mathrm{ABb}$ & $29.1 \mathrm{~b}$ & 260 & 1.099 & 382 & $581 \mathrm{a}$ \\
\hline C-160 & $50.8 \mathrm{Aa}$ & $50.6 \mathrm{Aa}$ & $28.3 \mathrm{Bb}$ & $50.8 \mathrm{a}$ & 467 & 687 & 445 & $533 a$ \\
\hline Mean & $47 \mathrm{~A}$ & $49.9 \mathrm{~A}$ & $58.2 \mathrm{~A}$ & $47 \mathrm{~A}$ & $200 \mathrm{~B}$ & $534 \mathrm{~A}$ & $450 \mathrm{~A}$ & 395 \\
\hline CV $(\%)^{1}$ & \multicolumn{4}{|c|}{19.41} & \multicolumn{4}{|c|}{7.40} \\
\hline \multirow[t]{3}{*}{ CV $(\%)^{2}$} & \multicolumn{4}{|c|}{10.50} & \multicolumn{4}{|c|}{9.01} \\
\hline & \multicolumn{4}{|c|}{ Zn accumulation in stems } & \multicolumn{4}{|c|}{ Mn accumulation in stems } \\
\hline & \multicolumn{8}{|c|}{ (mg plant $\left.{ }^{-1}\right)$} \\
\hline C-057 & 94.2 & 116.9 & 27.4 & $79.5 \mathrm{a}$ & $378 \mathrm{Ab}$ & $373 \mathrm{Ab}$ & $256 \mathrm{Aa}$ & $335 a$ \\
\hline C-088 & 134.4 & 36.5 & 24.6 & $65.2 \mathrm{a}$ & $674 \mathrm{Aa}$ & $373 \mathrm{ABb}$ & $278 \mathrm{Ba}$ & $441 \mathrm{a}$ \\
\hline C-089 & 79.5 & 64.9 & 26.4 & 56.9 a & $670 \mathrm{Aa}$ & $425 \mathrm{ABb}$ & $260 \mathrm{Ba}$ & $451 \mathrm{a}$ \\
\hline C-125 & 107.9 & 97.5 & 27.5 & $77.6 \mathrm{a}$ & $945 \mathrm{Aa}$ & $718 \mathrm{ABa}$ & $390 \mathrm{Ba}$ & $684 a$ \\
\hline C-130 & 112.8 & 42.3 & 28.2 & $61.1 \mathrm{a}$ & $845 \mathrm{Aa}$ & $775 \mathrm{Aa}$ & $213 \mathrm{Ba}$ & $611 a$ \\
\hline C-160 & 57.4 & 43.5 & 74.1 & $58.3 a$ & $947 \mathrm{Aa}$ & $384 \mathrm{Bb}$ & $297 \mathrm{Ba}$ & $543 a$ \\
\hline Mean & $97.7 \mathrm{~A}$ & $66.9 \mathrm{AB}$ & $34.7 \mathrm{~B}$ & 66.4 & $743 \mathrm{~A}$ & $508 \mathrm{~A}$ & $282 \mathrm{~B}$ & 511 \\
\hline CV $(\%)^{1}$ & \multirow{2}{*}{\multicolumn{4}{|c|}{13.05}} & \multicolumn{4}{|c|}{10.34} \\
\hline CV $(\%)^{2}$ & & & & 16.43 & \multicolumn{4}{|c|}{4.78} \\
\hline
\end{tabular}

Means followed by the same letters, uppercase in the row and lowercase in the column, do not differ by Tukey and Scott-Knott tests, respectively, both at $\mathrm{p} \leq 0.05$; Cu - Copper; Fe Iron; $\mathrm{Zn}$ - Zinc; Mn - Manganese; ${ }^{1}$ Coefficient of variation of the subplot (period); ${ }^{2}$ Coefficient of variation of the plot (genotype)

September (Table 4). Such higher nutrient export in September is directly related to the higher number of viable cuttings and higher dry mass accumulation (Prezotti \& Bragança, 2013) obtained in this period, that is, the higher the quantity of plant 
Table 4. Export of macronutrients by cuttings (clonal propagules) of 'Conilon' Coffea canephora genotypes in different periods of the year

\begin{tabular}{|c|c|c|c|c|c|c|c|c|}
\hline & Jan & May & Sep & Mean & Jan & May & Sep & Mean \\
\hline \multirow[t]{2}{*}{ Genotype } & \multicolumn{4}{|c|}{ N export by cultings } & \multicolumn{4}{|c|}{ P export by cuttings } \\
\hline & \multicolumn{8}{|c|}{$\left(\right.$ mg plant $\left.^{-1}\right)$} \\
\hline C-057 & 2,713 & 4,419 & 5,296 & $4,143 \mathrm{a}$ & 161 & 292 & 371 & $275 a$ \\
\hline C-088 & 3,137 & 4,613 & 4,259 & $4,003 \mathrm{a}$ & 184 & 306 & 257 & $249 a$ \\
\hline C-089 & 2,102 & 2,913 & 3,318 & $2,777 \mathrm{a}$ & 120 & 179 & 188 & $162 \mathrm{a}$ \\
\hline C-125 & 2,484 & 3,623 & 4055 & $3,387 \mathrm{a}$ & 114 & 216 & 228 & $186 \mathrm{a}$ \\
\hline C-130 & 2,509 & 3,340 & 3,649 & $3,166 \mathrm{a}$ & 144 & 206 & 233 & $194 \mathrm{a}$ \\
\hline C-160 & 2,513 & 3,130 & 4,252 & $3,298 \mathrm{a}$ & 160 & 177 & 240 & $193 a$ \\
\hline Mean & $2,576 \mathrm{~B}$ & $3,673 \mathrm{AB}$ & $4,138 \mathrm{~A}$ & 3,462 & 147 B & $229 \mathrm{~A}$ & $253 \mathrm{~A}$ & 210 \\
\hline CV $(\%)^{1}$ & \multirow{2}{*}{\multicolumn{4}{|c|}{$\begin{array}{c}17.73 \\
9.99\end{array}$}} & \multicolumn{4}{|c|}{20.01} \\
\hline \multirow[t]{3}{*}{ CV $(\%)^{2}$} & & & & & & & & \\
\hline & \multicolumn{4}{|c|}{ K export by cuttings } & \multicolumn{4}{|c|}{ Ca export by cuttings } \\
\hline & \multicolumn{8}{|c|}{ (mg plant $\left.^{-1}\right)$} \\
\hline C-057 & 3,492 & 5,169 & 6,750 & $5,137 a$ & 1,436 & 1,962 & 3,088 & $2,162 \mathrm{a}$ \\
\hline C-088 & 4,679 & 5,799 & 6,054 & $5,511 \mathrm{a}$ & 1,720 & 2,187 & 2,695 & $2,201 \mathrm{a}$ \\
\hline C-089 & 3,244 & 3,578 & 5,047 & $3,956 \mathrm{a}$ & 916 & 1,085 & 1,603 & $1,201 \mathrm{a}$ \\
\hline C-125 & 3,903 & 4,525 & 5,736 & $4,722 \mathrm{a}$ & 996 & 1,146 & 1,323 & $1,155 \mathrm{a}$ \\
\hline C-130 & 3,252 & 3,813 & 5,386 & $4,151 \mathrm{a}$ & 1,289 & 1,415 & 1,632 & $1,445 a$ \\
\hline C-160 & 3,391 & 3,352 & 5,640 & $4,128 \mathrm{a}$ & 1,357 & 1,278 & 2,087 & $1,574 a$ \\
\hline Mean & $3,660 \mathrm{~B}$ & $4,373 \mathrm{AB}$ & $5,769 \mathrm{~A}$ & 4,601 & $1,286 \mathrm{~B}$ & $1,512 A B$ & $2,071 \mathrm{~A}$ & 1,623 \\
\hline CV $(\%)^{1}$ & \multicolumn{4}{|c|}{4.54} & \multicolumn{4}{|c|}{20.01} \\
\hline \multirow[t]{3}{*}{$\operatorname{CV}(\%)^{2}$} & \multicolumn{4}{|c|}{2.29} & \multicolumn{4}{|c|}{11.19} \\
\hline & \multicolumn{4}{|c|}{ Mg export by cultings } & \multicolumn{4}{|c|}{ S export by cuttings } \\
\hline & \multicolumn{8}{|c|}{$\left(\mathrm{mg} \mathrm{plant}^{-1}\right)$} \\
\hline C-057 & 288 & 395 & 680 & $454 \mathrm{a}$ & 172 & 194 & 392 & $253 \mathrm{a}$ \\
\hline C-088 & 255 & 388 & 427 & $357 \mathrm{a}$ & 199 & 211 & 237 & $216 \mathrm{a}$ \\
\hline C-089 & 158 & 240 & 335 & $244 \mathrm{a}$ & 102 & 133 & 205 & 147 a \\
\hline C-125 & 162 & 259 & 288 & $236 \mathrm{a}$ & 192 & 182 & 236 & $203 a$ \\
\hline C-130 & 179 & 270 & 293 & $247 \mathrm{a}$ & 178 & 198 & 273 & $216 \mathrm{a}$ \\
\hline C-160 & 217 & 226 & 381 & $275 \mathrm{a}$ & 140 & 131 & 200 & $157 \mathrm{a}$ \\
\hline Mean & $210 B$ & $296 \mathrm{AB}$ & $401 \mathrm{~A}$ & 302 & 164 B & $175 \mathrm{AB}$ & $257 \mathrm{~A}$ & 199 \\
\hline CV $(\%)^{1}$ & \multicolumn{4}{|c|}{7.30} & \multicolumn{4}{|c|}{22.03} \\
\hline CV $(\%)^{2}$ & \multicolumn{4}{|c|}{4.14} & \multicolumn{4}{|c|}{12.54} \\
\hline
\end{tabular}

Means followed by the same letters, uppercase in the row and lowercase in the column, do not differ by Tukey and Scott-Knott tests, respectively, both at $\mathrm{p} \leq 0.05$; $\mathrm{N}$ - Nitrogen; $\mathrm{P}$. Phosphorus; K - Potassium; Ca - Calcium; Mg - Magnesium; S - Sulfur; ${ }^{1}$ Coefficient of variation of the subplot (period); ${ }^{2}$ Coefficient of variation of the plot (genotype)

material removed from the clonal garden, the larger the export of macro- and micronutrients.

The export of macronutrients by the cuttings of the clonal garden followed the following order: $\mathrm{K}>\mathrm{N}>\mathrm{Ca}>\mathrm{Mg}>\mathrm{P}>\mathrm{S}$ (Table 4). This sequence is different from that reported for the nutrient export by fruits, $\mathrm{N}>\mathrm{K}>\mathrm{Ca}>\mathrm{P}>\mathrm{S}>\mathrm{Mg}$ (Covre et al., 2016). These sequences diverge with respect to the order of the first and second most exported nutrients, $\mathrm{N}$ and $\mathrm{K}$, and in the position of $\mathrm{Mg}$, which in fruits is the sixth most exported nutrient, whereas in the cutting it is the fourth most exported, ahead of $\mathrm{P}$ and $\mathrm{S}$.

In the case of $\mathrm{K}$, the nutrient most exported by the cutting, ahead of $\mathrm{N}$, unlike what occurs in fruits, its higher concentration in the cutting can contribute to lower cutting dehydration in the nursery. This is because $\mathrm{K}$ is related to the maintenance of cell turgor (Taiz et al., 2017) and to stomatal regulation (Cunha et al., 2009). However, it should be considered that there was high availability of $\mathrm{K}$ in the soil, $0.57 \mathrm{cmol}_{\mathrm{c}} \mathrm{dm}^{-3}$ in the $0-20$ $\mathrm{cm}$ layer, which may have promoted consumption above the physiological needs of the plant.

For $\mathrm{Mg}$, the higher concentration of this nutrient in the cutting is related to its functions in the plant, especially in the composition of the chlorophyll molecule (Taiz et al., 2017), which is present in both the leaf and the herbaceous stem of the cutting. Thus, for the nutritional management of the clonal garden, its peculiarities should be considered and, therefore, it should not be managed in the same way as commercial orchards intended for fruit production.

For the export of micronutrients, the cuttings produced from orthotropic stems collected in September showed higher export of Fe and $\mathrm{Zn}$, regardless of genotype (Table 5). Cu export was higher for the genotypes C- 057 and C- 125 by the cuttings produced in September. On the other hand, Mn was the only micronutrient exported in similar quantities by the cuttings in the different periods. The decreasing sequence of micronutrient export by the cuttings was $\mathrm{Mn}>\mathrm{Fe}>\mathrm{Zn}>\mathrm{Cu}$, respectively. These results reinforce the idea that not only the accumulation of nutrients in orthotropic stems, but the pattern of macro- and micronutrient export in the present study are more related to the period of collection than to the individual efficiency of each genotype to absorb nutrients because, among the evaluated genotypes, none of the materials stood out as more promising in the accumulation of macro- and micronutrients for the different periods evaluated.

Information on the amount of nutrients exported from the clonal garden through the removal of cuttings for the production of plantlets guides its fertilizer replacement, given that fertilizer replacement in clonal gardens is currently based on the production fertilization of commercial orchards. However, other factors should be considered when it comes to fertilizer replacement in clonal gardens, because the nutrients that return to the system through the dry mass of the remaining 
Table 5. Export of micronutrients by cuttings (clonal propagules) of 'Conilon' Coffea canephora coffee genotypes in different periods of the year

\begin{tabular}{|c|c|c|c|c|c|c|c|c|}
\hline \multirow{3}{*}{ Genotype } & Jan & May & Sep & Mean & Jan & May & Sep & Mean \\
\hline & \multicolumn{4}{|c|}{ Cu export by cuttings } & \multicolumn{4}{|c|}{ Fe export by cuttings } \\
\hline & \multicolumn{8}{|c|}{$\left(\mathrm{mg} \mathrm{plant}^{-1}\right)$} \\
\hline C-057 & $2.5 \mathrm{Ca}$ & $5.5 \mathrm{Ba}$ & $17.8 \mathrm{Aa}$ & $8.6 \mathrm{a}$ & 18.9 & 45.7 & 46.7 & $37.1 \mathrm{a}$ \\
\hline C-088 & $2.9 \mathrm{Ca}$ & $5.1 \mathrm{Ba}$ & $10.3 \mathrm{Ab}$ & $6.1 \mathrm{a}$ & 11.9 & 19 & 38 & $23 \mathrm{a}$ \\
\hline C-089 & $2.1 \mathrm{Ba}$ & $3.3 \mathrm{Bb}$ & $13.8 \mathrm{Ab}$ & $6.4 \mathrm{a}$ & 16.2 & 12.3 & 37.8 & $22.1 \mathrm{a}$ \\
\hline C-125 & $3.2 \mathrm{Ca}$ & $6 \mathrm{Ba}$ & $15.1 \mathrm{Aa}$ & $8.1 \mathrm{a}$ & 5.5 & 14.5 & 49.9 & $23.3 \mathrm{a}$ \\
\hline C-130 & $2.9 \mathrm{Ca}$ & $6.4 \mathrm{Ba}$ & $11.5 \mathrm{Ab}$ & $6.9 \mathrm{a}$ & 5 & 23.5 & 31.9 & $20.2 \mathrm{a}$ \\
\hline C-160 & $3.7 \mathrm{Ba}$ & $3.9 \mathrm{Bb}$ & $11.4 \mathrm{Ab}$ & $6.3 \mathrm{a}$ & 9.4 & 15.4 & 40.1 & $21.6 \mathrm{a}$ \\
\hline Mean & $2.9 \mathrm{C}$ & $5 B$ & $13.3 \mathrm{~A}$ & 7.1 & $11.1 \mathrm{~B}$ & $21.7 \mathrm{~B}$ & $40.7 \mathrm{~A}$ & 24.5 \\
\hline CV (\%) ${ }^{1}$ & \multirow{2}{*}{\multicolumn{4}{|c|}{$\begin{array}{l}22.37 \\
14.18\end{array}$}} & \multicolumn{4}{|c|}{35.60} \\
\hline \multirow[t]{3}{*}{ CV $(\%)^{2}$} & & & & & & & & \\
\hline & \multicolumn{4}{|c|}{ Zn export by cuttings } & \multicolumn{4}{|c|}{ Mn export by cuttings } \\
\hline & \multicolumn{8}{|c|}{ (mg plant $\left.{ }^{-1}\right)$} \\
\hline C-057 & $8.9 \mathrm{Ba}$ & $2.4 \mathrm{Ca}$ & $85.1 \mathrm{Aa}$ & $32.1 \mathrm{a}$ & 33 & 28.5 & 42.2 & $34.6 \mathrm{~b}$ \\
\hline C-088 & $12.2 \mathrm{Ba}$ & $3.7 \mathrm{Ca}$ & $53.2 \mathrm{Aa}$ & $23 a$ & 33.6 & 32.3 & 33.5 & $33.1 \mathrm{~b}$ \\
\hline C-089 & $7.2 \mathrm{Ba}$ & $2.7 \mathrm{Ca}$ & $30 \mathrm{Aa}$ & $13.3 \mathrm{a}$ & 51.1 & 39.2 & 51.4 & $47.3 \mathrm{a}$ \\
\hline C-125 & $9.8 \mathrm{Ba}$ & $6 \mathrm{Ca}$ & $35.3 \mathrm{Aa}$ & $17 \mathrm{a}$ & 55.4 & 65.7 & 63 & $61.4 \mathrm{a}$ \\
\hline C-130 & $7.6 \mathrm{Ba}$ & $6.4 \mathrm{Ca}$ & $18.2 \mathrm{Aa}$ & $10.7 \mathrm{a}$ & 81.5 & 50.7 & 57.4 & $63.2 \mathrm{a}$ \\
\hline C-160 & $8.4 \mathrm{Ba}$ & $1.9 \mathrm{Ca}$ & $19.9 \mathrm{Aa}$ & $10.1 \mathrm{a}$ & 58.5 & 40.2 & 55.2 & $51.3 a$ \\
\hline Mean & $9 \mathrm{~B}$ & $3.8 \mathrm{C}$ & $40.3 \mathrm{~A}$ & 17.7 & $52.2 \mathrm{~A}$ & $42.8 \mathrm{~A}$ & $50.5 \mathrm{~A}$ & 48.4 \\
\hline CV $(\%)^{1}$ & \multicolumn{4}{|c|}{26.18} & \multicolumn{4}{|c|}{30.57} \\
\hline CV $(\%)^{2}$ & \multicolumn{4}{|c|}{19.37} & \multicolumn{4}{|c|}{13.97} \\
\hline
\end{tabular}

Means followed by the same letters, uppercase in the row and lowercase in the column, do not differ by Tukey and Scott-Knott tests, respectively, both at $\mathrm{p} \leq 0.05$; Cu - Copper; Fe - Iron; Zn - Zinc; Mn - Manganese; ${ }^{1}$ Coefficient of variation of the subplot (period); ${ }^{2}$ Coefficient of variation of the plot (genotypes)

orthotropic stems of the cuttings undergo losses through several processes, such as immobilization (Lima et al., 2005), mineralization, volatilization (Diniz et al., 2014) and erosion (Sousa et al., 2012). Therefore, all nutrient losses should be taken into consideration for the fertilizer replacement.

\section{Conclusions}

1. The dry season, from May to September, leads to lower orthotropic stem dry mass accumulation by C. canephora parent plants, but allows obtaining a greater number of viable cuttings.

2. Nutrient accumulation by orthotropic stems intended for the production of cuttings follows the following descending order: $\mathrm{N}>\mathrm{K}>\mathrm{Ca}>\mathrm{Mg}>\mathrm{S}>\mathrm{P}>\mathrm{Mn}>\mathrm{Fe}>\mathrm{Zn}>\mathrm{Cu}$. The values are 47.1, 42.6, 17, 3.8, 2.34 and 2.24 g per plant per cut for $\mathrm{N}, \mathrm{K}, \mathrm{Ca}, \mathrm{Mg}, \mathrm{S}$ and $\mathrm{P}$, respectively, and 511, 395, 66.4 and $47 \mathrm{mg}$ per plant per cut for $\mathrm{Mn}, \mathrm{Fe}, \mathrm{Zn}$ and $\mathrm{Cu}$.

3. The cuttings used for the production of clonal plantlets of C. canephora are responsible for average exports of 4,138 , 3,462, 1,623, 302, 210, 199, 48.4, 24.5, 17.7 and 7.1 mg per plant per cut of $\mathrm{K}, \mathrm{N}, \mathrm{Ca}, \mathrm{Mg}, \mathrm{P}, \mathrm{S}, \mathrm{Mn}, \mathrm{Fe}, \mathrm{Zn}$ and $\mathrm{Cu}$, respectively, from the clonal garden.

\section{ACKNowledgments}

To Consórcio Pesquisa Café, for the financial support, and to $\mathrm{CNPq}$ and CAPES for granting scholarships.

\section{Literature Cited}

Alvares, C. A.; Stape, J. L.; Sentelhas, P. C.; Gonçalves, J. L. M.; Sparovek, G. Koppen's climate classification map for Brazil. Meteorologische Zeitschrift, v.22, p.711-728, 2013. https://doi. org/10.1127/0941-2948/2013/0507
Amaral, J. F. T. do; Martinez, H. E. P.; Laviola, B. G.; Fernandes Filho, E. I.; Cruz, C. D. Eficiência de utilização de nutrientes por cultivares de cafeeiro. Ciência Rural, v.41, p.621-629, 2011. https:// doi.org/10.1590/S0103-84782011005000027

Aquino, L. P. de; Schmidt, R.; Dubberstein, D.; Dias, J. R. M. Cortes basais e substratos na formação de mudas de cafeeiro Canéfora. Coffee Science, v.12, p.9-16, 2017. https://doi.org/10.25186/ cs.v12i1.1182

Araújo, A. V.; Partelli, F. L.; Oliveira, M. G.; Pezzopane, J. R. M.; Falqueto, A. R.; Cavatte, P. C. Microclima e crescimento vegetativo do café conilon consorciado com bananeiras. Coffee Science, v.10, p.214-222, 2015.

Carmo, C. A. F. de S. do; Araújo, W. S. de; Bernardi, A. C. de C.; Saldanha, M. F. C. Métodos de análise de tecidos vegetais utilizados pela Embrapa Solos. Rio de Janeiro: Embrapa Solos, 2000. 41p.

Covre, A. M.; Rodrigues, W. P.; Vieira, H. D.; Braun, H.; Ramalho, J. C.; Partelli, F. L. Nutrient accumulation in bean and fruit from irrigated and non-irrigated Coffea canephora cv. Conilon. Emirates Journal of Food and Agriculture, v.28, p.402-409, 2016. https://doi.org/10.9755/ejfa.2016-04-341

Cunha, A. C. M. C. M. da; Paiva, H. N. de; Barros, N. F. de; Leite, H. G.; Leite, F. P. Relação do estado nutricional de minicepas com o enraizamento de miniestacas de eucalipto. Revista Brasileira de Ciência do Solo, v.33, p.591-599, 2009. https://doi.org/10.1590/ S0100-06832009000300012

Diniz, E. R.; Vargas, T. de O.; Pereira, W. D.; Guedes, A. F.; Santos, R. H. S.; Peternelli, L. A. Decomposição e mineralização do nitrogênio proveniente do adubo verde Crotalaria juncea. Científica, v.42, p.51-59, 2014. https://doi.org/10.15361/1984$5529.2014 \mathrm{v} 42 \mathrm{n} 1 \mathrm{p} 51-59$

Dubberstein, D.; Partelli, F. L.; Dias, J. R. M.; Espindula, M. C. Influência da adubação no crescimento vegetativo de cafeeiros na Amazônia sul ocidental. Coffee Science, v.12, p.197-206, 2017. https://doi.org/10.25186/cs.v12i2.1228 
Espindula, M. C.; Mauri, A. L.; Ramalho, A. R.; Dias, J. R. M.; Ferreira, M. das G. R.; Santos, M. R. A. dos; Marcolan, A. R. Produção de mudas. In: Marcolan, A. R.; Espindula, M. C. Café na Amazônia. Brasília: Embrapa Informação Tecnológica, 2015. Cap.6, p.129-154.

Ferrão, R. G.; Fonseca, A. F. A. da; Bragança, S. M.; Ferrão, M. A. G.; Muner, L. H. de. Café conilon. Vitória: Incaper, 2017. 702p.

INPE - Instituto Nacional de Pesquisas Espaciais. 2018. Available on: <http://www.obt.inpe.br/OBT/assuntos/programas/amazonia/ prodes $>$. Accessed on: Jun. 2018.

Laviola, B. G.; Martinez, H. E. P.; Souza, R. B. de; Venegas, V. H. A. Dinâmica de $\mathrm{N}$ e $\mathrm{K}$ em folhas, flores e frutos de cafeeiro arábico em três níveis de adubação. Bioscience Journal, v.22, p.33-47, 2006.

Lavres Junior, J.; Nogueira, T. A. R.; Cabral, C. P.; Malavolta, E. Deficiências de macronutrientes no crescimento e na produção da mamoneira cultivar Iris. Revista Brasileira de Ciências Agrárias, v.4, p.405-413, 2009. https://doi.org/10.5039/agraria.v4i4a6

Lima, H. N.; Mello, J. W. V. de; Schaefer, C. E. G. R.; Ker, J. C. Dinâmica da mobilização de elementos em solos da Amazônia submetidos à inundação. Acta Amazônica, v.35, p.317-330, 2005. https://doi. org/10.1590/S0044-59672005000300003

Marcolan, A. L.; Espindula, M. C.; Mendes, A. M.; Souza, K. W. de; Schlindwein, L. A. Manejo Nutricional. In: Marcolan, A. R.; Espindula, M. C. Café na Amazônia. Brasília: Embrapa Informação Tecnológica, 2015. Cap.8, p.175-194.

Martins, M. Q.; Rodrigues, W. P.; Fortunato, A. S.; Leitão, A. E.; Rodrigues, A. P.; Pais, I. P.; Martins, L. D.; Silva, M. J.; Reboredo, F. H.; Partelli, F. L.; Campostrini, E.; Tomaz, M. A.; ScottiCampos, P.; Ribeiro-Barros, A. I.; Lidon, F. C.; Matta, F. M. da; Ramalho, J. C. Protective response mechanisms to heat stress in interaction with high $\left[\mathrm{CO}_{2}\right]$ conditions in Coffea spp. Frontiers in Plant Science, v.7, p.1-18, 2016. https://doi.org/10.3389/ fpls.2016.00947

Partelli, F. L.; Espindula, M. C.; Marré, W. B.; Vieira, H. D. Dry matter and macronutrient accumulation in fruits of conilon coffee with different ripening cycles. Revista Brasileira de Ciência do Solo, v.38, p.214-222, 2014. https://doi.org/10.1590/S010006832014000100021

Partelli, F. L.; Vieira, H. D.; Santiago, A. R.; Barroso, D. G. Produção e desenvolvimento radicular de plantas de café 'Conilon' propagadas por sementes e por estacas. Pesquisa Agropecuária Brasileira, v.41, p.949-954, 2006. https://doi.org/10.1590/S0100204X2006000600008
Prezotti, L. C.; Bragança, S. M. Acúmulo de massa seca, N, P e K em diferentes materiais genéticos de café conilon. Coffee Science, v.8, p.284-294, 2013.

Ramalho, A. R.; Rocha, R. b.; Veneziano, W.; Santos, M. M. dos. Cultivar de cafeeiro Conilon BRS Ouro Preto - Características agronômicas e agroindustriais. Comunicado Técnico 396. EMBRAPA. p.1-10, 2014.

Rodrigues, W. P.; Jefferson, R. S.; Ferreira, L. S.; Machado Filho, J. A; Figueiredo, F. A. M. M. A.; Ferraz, T. M.; Bernado, W. P.; Bezerra, L. B. S.; Abreu de D. P.; Cespom, L.; Ramalho, J. C.; Campostrini, E. Stomatal and photochemical limitations of photosynthesis in coffee (Coffea spp.) plants subjected to elevated temperatures. Crop \& Pasture Science, v.69, p.317-325, 2018. https://doi. org/10.1071/CP17044

Rodrigues, W. P.; Martins, M. Q.; Fortunato, A. S.; Rodrigues, A. P.; Semedo, J. N.; Simões-Costa, M. C.; Pais, I. P.; Leitão, A. E.; Colwe, F.; Goulao, L.; Máguas, C.; Maia, R.; Partelli, F. L.; Campostrini, E.; Scotti-Campos, P.; Ribeiro-Barros, A. I.; Lidon, F. C.; Matta, F. M. da; Ramalho, J. C. Long-term elevated air $\left[\mathrm{CO}_{2}\right]$ strengthens photosynthetic functioning and mitigates the impact of supraoptimal temperatures in tropical Coffea arabica and C. canephora species. Global Change Biology, v.22, p.415-431, 2016. https://doi. org/10.1111/gcb.13088

Sadeghzadeh, B. A review of zinc nutrition and plant breeding. Journal of Soil Science and Plant Nutrition, v.13, p.905-927, 2013. https:// doi.org/10.4067/S0718-95162013005000072

Sousa, G. B.; Martins Filho, M. V.; Matias, S. S. R. Perdas de solo, matéria orgânica e nutrientes por erosão hídrica em uma vertente coberta com diferentes quantidades de palha de cana-de-açúcar em Guariba - SP. Engenharia Agrícola, v.32, p.490-500, 2012. https://doi.org/10.1590/S0100-69162012000300008

Souza, F. de F.; Ferrão, L. F. V.; Caixeta, E. T.; Sakiyama, N. S.; Pereira, A. A.; Oliveira, A. C. B. de. Aspectos gerais da biologia e da diversidade genética de Coffea canephora. In: Marcolan, A. L.; Espindula, M. C. (eds.). Café na Amazônia. Brasília: Embrapa Informação Tecnológica, 2015. Cap.4, p.85-95.

Taiz, L.; Zeiger, E.; Moller, I. M.; Murphy, A. Fisiologia e desenvolvimento vegetal. 6.ed. Porto Alegre: Artmed, 2017. 690p.

Thioune, E. H.; McCarthy, J.; Gallagher, T.; Osborne, B. A humidity shock leads to rapid, temperature dependent changes in coffee leaf physiology and gene expression. Tree Physiology, v.37, p.367-379, 2017. 